\title{
Foraging Behaviours of Wolverines at a Large Arctic Goose Colony
}

\author{
GUSTAF SAMELIUS, ${ }^{1,2}$ RAY T. ALISAUSKAS,,${ }^{1,3}$ SERGE LARIVIÈRE, ${ }^{1,4}$ CHRISTOFFER BERGMAN,${ }^{5}$ \\ CHRISTOPHER J. HENDRICKSON,${ }^{1}$ KIMBERLY PHIPPS ${ }^{1}$ and CREDENCE WOOD ${ }^{6}$
}

\author{
(Received 14 December 2000; accepted in revised form 17 September 2001)
}

\begin{abstract}
At the large Ross's goose and lesser snow goose colony at Karrak Lake, Nunavut, Canada, we saw wolverines kill two geese, take 13 eggs from 12 goose nests, and take three goose carcasses from two fox dens. Wolverines also made unsuccessful attempts to capture geese and frequently ignored eggs from nests where geese had fled the approaching wolverine. Most foods (all geese killed by wolverines and $80 \%$ of the eggs) were cached for later use, whereas few foods were eaten immediately ( $20 \%$ of the eggs and part of a goose taken from a fox den, which was later lost) or lost (all geese taken from fox dens). Wolverines spent little time caching foods (e.g., some foods were never covered), which suggests that recovery of these foods was not crucial to wolverines. When taking foods from fox dens, wolverines were mobbed by foxes; as a result, only one wolverine managed to consume part of a goose carcass taken from a fox den. These observations illustrate the opportunistic nature of wolverines and suggest that their scavenging success may be influenced by how well foods are defended.
\end{abstract}

Key words: wolverine, Gulo gulo, foraging behaviour, food caching, predation, scavenging, Ross's goose, Chen rossii, lesser snow goose, Chen caerulescens, arctic fox, Alopex lagopus, Queen Maud Gulf Bird Sanctuary

RÉSUMÉ. À l'importante colonie d'oies de Ross et de petites oies des neiges située à Karrak Lake au Nunavut (Canada), on a vu des carcajous tuer deux oies, prendre 13 oeufs dans 12 nids d'oies, et prendre trois carcasses d'oies dans deux terriers de renards. Les carcajous ont aussi essayé, sans succès, de capturer des oies et ils ignoraient souvent les oeufs des nids que les oies avaient fuis à leur approche. La plupart des aliments (toutes les oies tuées par les carcajous et $80 \mathrm{p}$. cent des oeufs) étaient dissimulés pour utilisation ultérieure, tandis que peu d'aliments étaient consommés tout de suite (20 p. cent des oeufs et une partie d'une oie prélevée dans un terrier de renard, qui a été perdue par la suite) ou perdus (toutes les oies prises dans les terriers de renards). Les carcajous passaient peu de temps à dissimuler les aliments (p. ex., certains n'étaient jamais recouverts), ce qui suggère qu'il n'est pas crucial pour eux de les retrouver. Quand les carcajous prenaient des aliments dans les terriers de renards, ils étaient assaillis par les occupants; en conséquence, un seul carcajou est parvenu à consommer une partie d'une carcasse d'oie prise dans un terrier de renard. Ces observations illustrent la nature opportuniste des carcajous et suggèrent que leur succès de récupération pourrait être influencé par la façon dont les aliments sont défendus.

Mots clés: carcajou, Gulo gulo, comportement de recherche de nourriture, dissimulation d'aliments, prédation, récupération, oie de Ross, Chen rossii, petite oie des neiges, Chen caerulescens, renard arctique, Alopex lagopus, Refuge d'oiseaux du golfe Reine-Maud

Traduit pour la revue Arctic par Nésida Loyer.

\section{INTRODUCTION}

Wolverines (Gulo gulo) are opportunistic predators and scavengers that feed on a variety of foods throughout their circumpolar range (Pasitschniak-Arts and Larivière, 1995). In fact, wolverines are well adapted to scavenging, and carrion can form a large portion of wolverine diets (Hornocker and Hash, 1981; Magoun, 1987, Landa et al., 1997). Wolverines cache foods when they are abundant, and subsequent consumption of these foods may be important during food shortages or to supplement the diet of growing young (Vander Wall, 1990; Pasitschniak-Arts and Larivière, 1995). However, the extent and implications of food caching by wolverines and other carnivores are poorly understood (Vander Wall, 1990). Further, wolverines are rarely seen in the wild, and wolverine foraging behaviours are therefore poorly documented (see Pasitschniak-Arts and Larivière, 1995). Here we report on foraging behaviours of wolverines observed at a large arctic goose colony.

\footnotetext{
${ }^{1}$ Department of Biology, University of Saskatchewan, 112 Science Place, Saskatoon, Saskatchewan S7N 5E2, Canada

${ }^{2}$ Corresponding author: gustaf.samelius@ec.gc.ca

${ }^{3}$ Canadian Wildlife Service, 115 Perimeter Road, Saskatoon, Saskatchewan S7N 0X4, Canada

${ }^{4}$ Ducks Unlimited Inc., One Waterfowl Way, Memphis, Tennessee 38120-3925, U.S.A.; present address: Delta Waterfowl Foundation, R.R. \#1, Box 1, Portage La Prairie, Manitoba R1N 3A1, Canada

${ }^{5}$ Frösövägen 42, 83244 Frösön, Sweden

${ }^{6}$ Integrated Resource Management Department, Saskatchewan Institute of Applied Science \& Technology - Woodland Campus, 1100

15 Street East, Prince Albert, Saskatchewan S6V 6G1, Canada

(C) The Arctic Institute of North America
} 


\section{METHODS}

Observations were made at the Karrak Lake goose colony $\left(67^{\circ} 14^{\prime} \mathrm{N}, 100^{\circ} 15^{\prime} \mathrm{W}\right)$ in Nunavut, Canada, during the summer of 2000 as part of a study on the ecology of arctic foxes (Alopex lagopus). The goose colony at Karrak Lake is the largest in the Queen Maud Gulf Bird Sanctuary (Kerbes, 1994). In 2000, it consisted of about 706000 nesting Ross's geese (Chen rossii) and lesser snow geese (Chen caerulescens) (R. Alisauskas, unpubl. data). Karrak Lake and surrounding areas consist of gently rolling tundra that is dominated by rock outcrops, sedge meadows, and marshy areas interrupted by shallow tundra ponds (Ryder, 1972). Visibility was over $0.5 \mathrm{~km}$ in all areas from which observations were made.

Wolverines were observed opportunistically while we monitored foraging behaviours of arctic foxes and activity at arctic fox dens or rested during other work. All aspects of the work were done between 15 June and 13 July. Wolverines were observed with spotting scopes or binoculars until either they disappeared from view, or the distance became too great for accurate observations, or they appeared to notice our presence. One observation was made at a fox den where we had placed an unbaited wiremesh trap; the trap did not appear to affect either the wolverine or the foxes. Observations were made at distances ranging from ca. $30 \mathrm{~m}$ to $1 \mathrm{~km}$, and all observations occurred during the nesting season of the geese. Wolverines were observed in three general areas of the colony that were $6-7 \mathrm{~km}$ apart. Wolverines were not marked, so the sex, age, and number of individuals observed are unknown; however, we concluded on the basis of pelt pattern that there were at least two animals.

\section{RESULTS}

We observed wolverines foraging in the colony on nine occasions during the nesting season of geese (Table 1) for periods of 2-15 minutes, during which wolverines killed two geese, took 13 eggs from 12 goose nests, and took three goose carcasses from two fox dens. In all cases, it was unknown whether birds were Ross's geese or lesser snow geese. One wolverine was seen carrying a goose carcass that was acquired from an unknown source. All eggs were taken from nests where geese had fled the approaching wolverine. Wolverines made 11 or 12 unsuccessful attempts to capture geese. The wolverines travelled relatively straight and attacked geese by making short rushes $(<15 \mathrm{~m})$, often jumping towards the geese as they fled. Wolverines frequently ignored eggs from nests where geese had fled the approaching wolverine. All geese within ca. $15 \mathrm{~m}$ of the wolverine fled their nests, and wolverines ignored more than 100 nests during our observations.

Both geese that were killed were cached among rocks within 2-4 minutes of being captured, and only one goose appeared to be covered by debris. When taking foods from fox dens, the wolverines were mobbed by foxes (two foxes defended foods at one den and one fox at the other den). The foxes generally barked, approached wolverines from behind, and appeared to attempt biting wolverines. As a result, only one wolverine managed to consume part of a goose carcass taken from a fox den. Wolverines left the dens without any food in both cases, and the foxes recovered all foods. The goose carcass acquired from an unknown source was carried for more than five minutes (i.e., throughout the observation), during which time the wolverine moved over $1 \mathrm{~km}$.

Most eggs ( $n=8$ eggs) were cached for later use, whereas few eggs $(n=2$ eggs) were eaten immediately. Three eggs had unknown fates. Eggs were cached or consumed within ca. 30 seconds of being removed from nests, and eggs of unknown fate also were never handled for more than ca. 30 seconds. Wolverines spent little or no time $(<5 \mathrm{sec})$ covering eggs. Five eggs were covered, and three were uncovered. We considered uncovered eggs as cached because we were unable to tell whether they were placed in locations that might prevent other animals from finding them (see Vander Wall, 1990). Wolverines never dug before caching eggs, and we never observed wolverines urinating or otherwise marking their caches.

\section{DISCUSSION}

Wolverines at Karrak Lake exploited available foods by either killing geese, taking eggs from goose nests, or taking foods from fox dens. These observations illustrate the opportunistic nature of wolverines and further show that wolverines scavenge foods acquired by other animals (see Hornocker and Hash, 1981; Magoun, 1987; Landa et al., 1997). However, because of harassment by foxes, only part of the food scavenged from fox dens was consumed, suggesting that the scavenging success of wolverines may be influenced by how well foods are defended. Scavenging success may also vary with factors such as hunger and availability of other foods. In addition to wolverines, we also saw a wolf (Canis lupus) and a grizzly bear (Ursus arctos) scavenging foods from fox dens. These observations suggest that the cost of losing foods to scavengers, in combination with the risk of pup loss to predation, may select for high parental attendance by arctic foxes (see Garrott and Eberhardt, 1982).

While most foods were cached for later use, wolverines did not invest much time in caching foods (e.g., some foods were not covered), which suggests that recovery of these foods was not crucial to wolverines. Perhaps most of the acquisition of small food items that we observed was incidental to foraging for larger foods (e.g., dead caribou). Low investment in food caching by wolverines differs markedly from the behaviour of arctic foxes: foxes often spend 5-10 minutes caching such foods, carefully covering each cache (Samelius and Alisauskas, 2000). Differences in caching behaviour between these species may 
TABLE 1. Foraging behaviours of wolverines at the Karrak Lake goose colony in the summer of 2000. We classed fate of foods as eaten, cached, or unknown. All eggs except the two eggs acquired during the second observation on 29 June were from different nests.

\begin{tabular}{|c|c|c|c|}
\hline Date & Length of Observation & Foods Taken or Handled & Fate of Foods \\
\hline 18 June & ca. $5 \mathrm{~min}$ & took 4 eggs & 1 egg eaten, 3 eggs cached ( 1 covered, 2 uncovered) \\
\hline 20 June & $14 \mathrm{~min}$ & killed 2 geese, took 1 egg, charged 5 pairs & cached geese, egg unknown fate \\
\hline 20 June & $4 \mathrm{~min}$ & took 3 eggs, charged 1 pair & all eggs cached ( 2 covered, 1 uncovered) \\
\hline 29 June & ca. $15 \mathrm{~min}$ & took 2 eggs, charged 5-6 pairs & both eggs cached (both covered) \\
\hline 29 June & ca. $2 \mathrm{~min}$ & took 2 eggs & 1 egg eaten, 1 egg unknown fate \\
\hline 2 July & $4 \mathrm{~min}$ & appeared to take 1 egg & unknown fate \\
\hline 2 July & ca. $5 \mathrm{~min}$ & carried goose, visited fox den & unknown fate \\
\hline 7 July & ca. $5 \mathrm{~min}$ & took 2 geese from a fox den & mobbed by 2 foxes, fed partially on 1 goose \\
\hline 13 July & ca. $8 \mathrm{~min}$ & took 1 goose from a fox den & mobbed by 1 fox, left den without feeding on the goose \\
\hline
\end{tabular}

reflect the fact that wolverines range over much greater areas than arctic foxes and therefore have lower potential to defend and recover cached foods (see Hornocker and Hash, 1981). Food caching by wolverines may still be adaptive, however, if foods can be obtained and cached at a low cost (i.e., at little expenditure of energy and low risk of injury). Wolverines may also invest more time in caching foods in areas where food is less abundant than at Karrak Lake.

Wolverines appeared to invest more time in caching geese than in caching eggs, which suggests that recovery of geese was more important to wolverines. Similarly, wolverines frequently ignored eggs from geese that fled at their approach and usually took only a single egg from each nest (average clutch size in 2000 was 2.9 eggs per clutch for both Ross's geese and lesser snow geese; Alisauskas, unpubl. data), but made several unsuccessful attempts to capture geese. Wolverines may have focused their foraging effort on geese because birds offer higher energy return or greater nutritional value than eggs (see Bantle and Alisauskas, 1998). Recovery of cached geese may have been limited, however, as we found a rotting lesser snow goose carcass hidden among the rocks where we had seen a wolverine cache a goose 13 days before.

\section{ACKNOWLEDGEMENTS}

We thank K. Hobson, A. Magoun, J. Whitman, and an anonymous reviewer for valuable comments on this manuscript; J. Aitaok, B. Eyegetok, and D. Stern for assistance and hospitality in Cambridge Bay; and S. Vander Wall for comments on food caching. This study was funded by the California Department of Fish and Game, Canadian Wildlife Service, Ducks Unlimited, the Polar Continental Shelf Project, and the University of Saskatchewan.

\section{REFERENCES}

BANTLE, J.L., and ALISAUSKAS, R.T. 1998. Spatial and temporal patterns in arctic fox diets at a large goose colony. Arctic 51:231-236.

GARROTT, R.A., and EBERHARDT, L.E. 1982. Mortality of arctic fox pups in northern Alaska. Journal of Mammalogy 63:173-174.

HORNOCKER, M.G., and HASH, H.S. 1981. Ecology of the wolverine in northwestern Montana. Canadian Journal of Zoology 59:1286-1301.

KERBES, R.H. 1994. Colonies and numbers of Ross' geese and lesser snow geese in the Queen Maud Gulf Bird Migratory Bird Sanctuary. Occasional Paper 81. Ottawa: Canadian Wildlife Service.

LANDA, A., STRAND, O., SWENSON, J.E., and SKOGLAND, T. 1997. Wolverines and their prey in southern Alaska. Canadian Journal of Zoology 75:1292-1299.

MAGOUN, A.J. 1987. Summer and winter diets of wolverines, Gulo gulo, in Arctic Alaska. Canadian Field-Naturalist 101: 392-397.

PASITSCHNIAK-ARTS, M., and LARIVIÈRE, S. 1995. Gulo gulo. Mammalian Species 499:1-10.

RYDER, J.P. 1972. Biology of nesting Ross' geese. Ardea 60: $185-215$.

SAMELIUS, G., and ALISAUSKAS, R.T. 2000. Foraging patterns of arctic foxes at a large arctic goose colony. Arctic 53: $279-288$.

VANDER WALL, S.B. 1990. Food hoarding in animals. Chicago: University of Chicago Press. 